\title{
Herbal medicine use during pregnancy in a group of Australian
} women

\author{
Della A Forster*1,2, Angela Denning2, Gemma Wills², Melissa Bolger and \\ Elizabeth McCarthy²
}

Address: ${ }^{1}$ Mother and Child Health Research, La Trobe University, 251 Faraday St, Carlton 3053, Australia and ${ }^{2}$ Mercy Hospital for Women, 163 Studley Rd, Heidelberg 3084, Australia

Email: Della A Forster* - d.forster@latrobe.edu.au; Angela Denning - angiekirsten@hotmail.com; Gemma Wills - ggainger@hotmail.com; Melissa Bolger - mbolger@mercy.com.au; Elizabeth McCarthy - emccarthy@mercy.com.au

* Corresponding author

Published: 19 June 2006

BMC Pregnancy and Childbirth 2006, 6:21 doi:10.1186/I47|-2393-6-21

This article is available from: http://www.biomedcentral.com/I47I-2393/6/2I

(C) 2006 Forster et al; licensee BioMed Central Ltd.

This is an Open Access article distributed under the terms of the Creative Commons Attribution License (http://creativecommons.org/licenses/by/2.0), which permits unrestricted use, distribution, and reproduction in any medium, provided the original work is properly cited.
Received: 03 November 2005

Accepted: 19 June 2006

\begin{abstract}
Background: There are limited data on the extent of women's use of herbal medicines during pregnancy, despite the fact that knowledge of the potential benefits or harms of many of these products is sparse, particularly with respect to their use in pregnancy. We aimed to measure the prevalence of herbal medicine use in a group of pregnant women attending a public tertiary maternity hospital in Melbourne, Australia. Secondary aims were to explore why women took the herbal medicine, where they received advice, what form the supplements took and if they perceived the supplements to be helpful.
\end{abstract}

Methods: Consecutive pregnant women were approached in the antenatal clinic and the birth centre at around 36-38 weeks gestation. A questionnaire was developed and self-administered in English, as well as being translated into the four most common languages of women attending the hospital: Cantonese, Vietnamese, Turkish and Arabic. Back translation into English was undertaken by different professional translators to verify accuracy of both words and concepts. Data collected included demographic information, model of pregnancy care and herbal supplement use. Descriptive statistics were used initially, with stratified and regression analysis to compare subgroups.

Results: Of 705 eligible women, 588 (83\%) agreed to participate. Of these, 88 (I5\%) completed the questionnaire in a language other than English. Thirty-six percent of women took at least one herbal supplement during the current pregnancy. The most common supplements taken were raspberry leaf (14\%), ginger (I2\%) and chamomile (I I\%). Women were more likely to take herbal supplements if they were older, tertiary educated, English speaking, non-smokers and primiparous.

Conclusion: Use of herbal supplements in pregnancy is likely to be relatively high and it is important to ascertain what supplements (if any) women are taking. Pregnancy care providers should be aware of the common herbal supplements used by women, and of the evidence regarding potential benefits or harm. 


\section{Background}

The use of complementary and alternative medicine (CAM) and therapies has increased in Australia $[1,2]$ as in many other developed countries [3,4], and $65-80 \%$ of the world's population use traditional medicine as their primary form of health care $[5,6]$. There are limited data on the extent of women's use of either herbal or vitamin supplements during pregnancy [7], despite the fact that knowledge of the potential side effects of many of these products is limited, particularly with respect to their use in pregnancy [8-11]. Although regulation of alternative medicines has improved in Australia herbal medicines are still not subject to the same scrutiny in terms of safety, efficacy and constituents as conventional medicines [2], although many consumers assume or expect this to be the case [12]. Many consumers do not inform their primary care provider about their use of these alternative medicines $[2,12]$.

Cross-sectional surveys in one Australian state in 1993, 2000 and 2004 demonstrated high levels of use of CAMs and CAM therapists $[1,2,12]$. While overall use of CAMs was stable, with approximately $50 \%$ of respondents using at least one non-medically prescribed alternative medicine in the previous year, there was an increased number of women using herbal medicines [12]. Users of CAM are more likely to be female, better educated, employed $[2,13,12]$ and have a higher income $[2,12]$.

Several papers specifically report on the use of herbal supplements or medicines in pregnancy, and the studies are summarised in Table 1. Herbal use reported in pregnancy ranged from $7 \%$ to $96 \%$. When considering only studies from Australia, use of herbal medicine in pregnancy ranged from $10-56 \%$. There is a trend that smaller studies have found higher prevalence of herbal medicine usage. Pinn and Pallett [14] reported a relatively low prevalence $(12 \%)$, but only asked women in mid-pregnancy, whereas Nordeng and Havnen [10] found that use of herbal supplements increased as pregnancy progressed, supporting trends noted in a previous Finnish study [15].

Characteristics of women more likely to take herbal supplements in pregnancy include being older [16]; married [8]; primiparous $[8,17]$; having tertiary level education [8]; previous herbal use [9]; being white [9]; and being less educated [9]. One study found older women were less likely to be taking herbal supplements [10]; another reported that the only predictor of increased use of herbal medicine in their study of nausea in pregnancy was increased severity of nausea and vomiting [18].

The use of herbal supplements during pregnancy may be pregnancy related, for example for nausea and vomiting $[19,7,8]$, reflux [7], candida [7], nutritional [10], or to prepare for labour [8]; or may be for unrelated health issues such as colds and respiratory illnesses [10] or skin problems [10]. Reasons reported for ceasing herbal medicine supplements during pregnancy include concerns for the health of the fetus/baby $[8,16,19]$, the 'condition' improving [8], the supplement not helping [8] and advice from a health care provider [16].

Herbal supplement use in pregnancy has been reported to be recommended by health care providers $[16,19]$, natu$\mathrm{ral} /$ alternative medicine practitioners $[18,19]$ or pharmacists [18]; suggested by friends or family $[8,10,16,18,19]$; based on information from media sources [19]; or based on women's own information and knowledge $[15,16]$. Women may choose to use herbal supplements because they consider them safer during pregnancy than pharmaceutical products [18]. MacLennan et al. [2] reported that nine percent of their sample considered that alternative medicines were safe to use in pregnancy, and $36 \%$ considered they were unsafe, with the remainder unsure (28\%) or varying depending on the medication $27 \%$.

Information on herbal use may not be specifically elicited during pregnancy care. One study found that $75 \%$ of women reported their supplement use during pregnancy to their primary care provider [19], and another reported that the use of herbal supplements were documented in only two $(1 \%)$ of the women's medical records where women had reported taking herbal supplements during study data collection [8]; it is not stated whether this was because women did not tell pregnancy providers or whether providers did not document the information. In an Australian study only $36 \%$ of participants informed their primary medical carer of alternative medicine usage [13].

Our aim was to explore patterns of herbal medication use including dietary supplements in pregnant women. We expected that in keeping with the increased use of herbal and alternative medicines in the community generally, we would find a relatively high proportion of women attending for pregnancy care were using herbal medicines periconceptionally, during pregnancy, labour or in the puerperium. We also expected that the use of herbal remedies might differ between cultural groups. This paper presents the findings relating to herbal medicine use in pregnancy.

Ethics approval was obtained from the Mercy Health and Aged Care Research Ethics Committee.

\section{Methods}

A cross-sectional survey design was used. The study was conducted at the Mercy Hospital for Women (MHW) in Melbourne, Australia, which is a large tertiary hospital with both midwifery and medical models of maternity 
Table I: Identified studies that have measured prevalence of use of herbal medicine in pregnancy

\begin{tabular}{|c|c|c|c|c|}
\hline Author, year, country & Design & Sample & Herbal use reported & Most common herbs \\
\hline $\begin{array}{l}\text { Byrne et. al. (2002), Adelaide, Australia } \\
\text { [24] }\end{array}$ & Structured interview & $\begin{array}{l}48 \text { antenatal inpatients with a variety of } \\
\text { diagnoses }\end{array}$ & $\begin{array}{l}56 \% \text { used herbal medicine or tea during } \\
\text { pregnancy }\end{array}$ & $\begin{array}{l}46 \text { herbal products used, most common: chamomile, } \\
\text { ginger, peppermint, raspberry leaf, valerian }\end{array}$ \\
\hline $\begin{array}{l}\text { Henry \& Crowther (2000), Adelaide, } \\
\text { Australia [7] }\end{array}$ & Structured interview & $\begin{array}{l}\text { I40/I6I (88\%) pregnant women of any } \\
\text { gestation }\end{array}$ & $10 \%$ used herbs in current pregnancy & $\begin{array}{l}\text { Evening primrose oil, antioxidants (no others } \\
\text { reported) }\end{array}$ \\
\hline $\begin{array}{l}\text { Maats \& Crowther (2002), Adelaide, } \\
\text { Australia [26] }\end{array}$ & Structured interview & $\begin{array}{l}211 \text { pregnant women } 26 \text { weeks } \\
\text { gestation onwards }\end{array}$ & $\begin{array}{l}\text { Overall herbal use in pregnancy not } \\
\text { stated. } 20 \% \text { used ginger and } 9 \% \\
\text { raspberry leaf tea }\end{array}$ & $\begin{array}{l}\text { Ginger, raspberry leaf tea, chamomile, echinacea, } \\
\text { evening primrose oil, slippery elm }\end{array}$ \\
\hline $\begin{array}{l}\text { Pinn \& Pallett, (2002), Nambour, } \\
\text { Australia [27] }\end{array}$ & Survey, self completed questionnaire & $\begin{array}{l}305 \text { consecutive women at booking ( } 16- \\
24 \text { weeks gestation }\end{array}$ & $12 \%$ used herbs in current pregnancy & $\begin{array}{l}\text { I5 herbs used: raspberry leaf, Chinese herbs, ginger, } \\
\text { St John's Wort, evening primrose, echinacea }\end{array}$ \\
\hline Hemminki et al. (1991), Finland [15] & $\begin{array}{l}3 \text { surveys, } 2 \text { retrospective. Structured } \\
\text { questionnaires. }\end{array}$ & $\begin{array}{l}\text { Study I: } 2912(94 \%) \text { pregnant women } \\
\text { Study 2: } 180 / 181 \text { postpartum women }\end{array}$ & $\begin{array}{l}\text { Study I: } 3.6 \% \text { and study } 2: 14 \% \text { of } \\
\text { women had used 'alternative' drugs } \\
\text { during pregnancy }\end{array}$ & $\begin{array}{l}\text { Limited information as supplements coded into } \\
\text { harmful, dangerous and possibly dangerous } \\
\text { categories. Dried cherry and natural lime most } \\
\text { common. } 25 \text { women had used supplements } \\
\text { potentially harmful to pregnancy e.g. St John's Wort. }\end{array}$ \\
\hline Gharoro \& Igbafe (2000), Nigeria [17] & $\begin{array}{l}\text { Cross-sectional, structured } \\
\text { questionnaire }\end{array}$ & 1200 pregnant women varied gestations & $12 \%$ used 'native' herbs & Not described \\
\hline Nordeng \& Havnen (2004), Norway [10] & Structured interview & 400 women 3 days postpartum & $36 \%$ used herbs in pregnancy & $\begin{array}{l}46 \text { herbs used, most common: echinacea, iron-rich } \\
\text { herbs, ginger, chamomile, cranberry, aloe, herbal } \\
\text { teas (mixed), horsetail, black elderberry, wheat } \\
\text { germ oil }\end{array}$ \\
\hline Gibson et. al. (200I), USA [9] & Prospective cross-sectional survey & $\begin{array}{l}250 \text { pregnant women (gestation not } \\
\text { reported in abstract) }\end{array}$ & $9.1 \%$ used herbs in current pregnancy & $\begin{array}{l}\text { Garlic, aloe, chamomile, peppermint, ginger, } \\
\text { echinacea, pumpkin seeds, ginseng }\end{array}$ \\
\hline Hepner et al. (2002), USA [16] & Postal survey- structured questionnaire & 734/I 203 (6I\%) pregnant women & $7.1 \%$ used herbs in current pregnancy & $\begin{array}{l}\text { Echinacea, ephedra, St John's Wort, ginger, ginko } \\
\text { biloba, gingseng, primrose, garlic, cranberry }\end{array}$ \\
\hline Tsui et. al. (200I), USA [19] & Survey, self completed questionnaire & $\begin{array}{l}150 \text { women in }\left.\right|^{\text {st }} \text { to } 3^{\text {rd }} \text { trimesters }(24 \% \\
\text { response rate) }\end{array}$ & $\begin{array}{l}13 \% \text { used dietary supplement during } \\
\text { pregnancy }\end{array}$ & $\begin{array}{l}45 \text { herbs used, most common: echinacea, pregnancy } \\
\text { tea**, ginger, vitamin } B_{6}^{*} \text {, vitamin } C^{*} \text {, multivitamin } \\
\text { with herbs, raspberry leaf }\end{array}$ \\
\hline \multicolumn{5}{|c|}{ Studies specifically concerned with nausea } \\
\hline Hollyer et al. (2002), Canada [18] & $\begin{array}{l}\text { Telephone survey, structured } \\
\text { questionnaire }\end{array}$ & $\begin{array}{l}70 / 110(64 \%) \text { pregnant women who rang } \\
\text { a nausea and vomiting telephone helpline }\end{array}$ & $\begin{array}{l}61 \% \text { used complementary or alternative } \\
\text { therapies overall. } 51 \% \text { used ginger }\end{array}$ & Only ginger mentioned \\
\hline Westfall (2004), Canada [28] & $\begin{array}{l}\text { Qualitative study, two semi-structured } \\
\text { interviews }\end{array}$ & $\begin{array}{l}27 \text { women in } 3 \text { rd trimester, } 23 / 27 \mathrm{I}-4 \\
\text { months postpartum. Women self- } \\
\text { selected into study }\end{array}$ & $\begin{array}{l}96 \% \text { used herbal medicine in pregnancy } \\
\text { (50\% of those with nauseas used herbs) }\end{array}$ & $\begin{array}{l}\text { For nausea, herbs used were: ginger, peppermint } \\
\text { and cannabis }\end{array}$ \\
\hline
\end{tabular}

* Other studies have not included vitamins, but here these were only reported by two women respectively

** Pregnancy tea contained a blend of herbs including spearmint, raspberry leaf, nettle etc.

care available to women. There are approximately 5,000 births per year at the MHW, and $80 \%$ book for maternity care as public patients. Private patients access antenatal care in the private rooms of their chosen provider.

\section{Participants}

Any woman attending a public antenatal clinic at the MHW, who had reached approximately 38 weeks gestation and who was able to speak and read English, Arabic, Chinese, Turkish or Vietnamese was eligible for inclusion in the study. The only exclusion criteria 
were if a woman or fetus were known to be very ill at the time of recruitment. Research midwives recruited women in the standard antenatal clinic as well as the Family Birth Centre clinic while the women were waiting for pregnancy check-ups. Women from the four language groups where information was translated were recruited with the assistance of interpreters where necessary, and used the translated questionnaires if they preferred or if it was necessary.

\section{Sample size}

We initially sought to recruit approximately $10 \%$ of the population of women going through the MHW each year, which would be 500 women. This covered a range of different sample size calculations for prevalence of herbal supplement use within the population. There were a wide range of variables being measured, and with many of them we had limited data from which to estimate expected prevalence. We looked at a variety of estimates from $5 \%$ to $50 \%$ (within which limits we estimated the true prevalence was likely to lie for the main supplements, based on previous studies), using a 95\% confidence level and allowing for a 5-10\% variation. The greatest number needed for this was 387 . Allowing for missing data within fields, as well as sub-group analysis, we rounded to 500 . Sample size calculations were undertaken using EpiInfo [20]. We aimed that $30 \%$ of the sample would comprise women from non English-speaking backgrounds, to represent the proportion of women booking to the MHW.

\section{Data collection}

A structured questionnaire was designed by the research team specifically for the project. The questionnaire was self-administered and took about 20 minutes to complete. Question areas included demographic factors (e.g. age, country of birth, religion, education, smoking status, income, marital status); and obstetric factors (e.g. parity, gestation, pregnancy losses, model of maternity care). A list of supplements and herbal preparations which we thought women were likely to take was included as a check list. These included ginger, raspberry leaf, chamomile, garlic, evening primrose oil, blue cohosh, ombeshi plums, black cohosh, echinacea, castor oil, cranberry juice, digestive bitters and slippery elm. Other supplements could be listed by the participants. Data on vitamin supplement use (e.g. folic acid) were also collected and will be reported elsewhere. Information was collected on dosage and form of supplements, duration and timing of treatment, who recommended the supplements and whether women thought that the supplement was effective. The questionnaire was piloted with a sample of women in the postnatal wards, and modifications made as necessary. Final piloting was undertaken using pregnant women in the antenatal clinic.
Approximately one third of the women booking into the MHW each year are from a non-English speaking background. The largest groups are Vietnamese, Chinese, Turkish and Arabic speaking women, and the questionnaire was translated into these four languages by qualified external translators. Translation back to English was undertaken by different translators to verify the content and to ensure that the concepts of the questions had not changed.

\section{Data analysis}

Data were entered on an Access database [21]. Quantitative data were analysed using Stata [22], and analysis included frequencies and summary descriptive statistics. Where logisitic regression was undertaken, variables were retained in at the univariate level if the $\mathrm{p}$-value was $\leq 0.2$, then in the main model if the p-value was $\leq 0.05$ [23]. A range of checks were done on final models. Data from open-ended responses were coded and presented as themes that best represented the data.

\section{Results}

The translated versions of the questionnaire took longer than anticipated to be finalised, so recruitment and data collection was in two phases. Women who could use the English version were recruited from May-October 2003. Women unable to complete the questionnaire in English were considered ineligible during this phase. There were 617 women eligible for the study and 500 (81\%) completed the survey. Eleven women declined participation and 107 were missed during the clinic due to scheduled activities, particularly medical, midwifery or ultrasound appointments. Arabic, Chinese, Turkish or Vietnamese speaking women were recruited between February and May 2004. There were 35 Vietnamese, 27 Chinese, 6 Turkish and 18 Arabic-speaking women. Other women from these language groups did participate but used the English version of the questionnaire, and were recruited in the first phase. The final sample size was 588 .

The background characteristics of the participants are presented in Table 2 . The majority of women were married, or living with a partner, had completed secondary education and did not smoke. Slightly less than half had completed a degree and had a household taxable income $>$ $\$ 50,000$ (AUD). Just over half of the women were having their first baby. Sixty-five percent of women had English as their first language

Table 3 shows the breakdown of the proportion of women who took herbal supplements; $36 \%$ of our sample took at least one herbal medicine supplement. The most common supplements used were raspberry leaf (13.9\%); ginger $(11.6 \%)$; chamomile $(11.1 \%)$; cranberry juice $(8.7 \%)$; echinacea $(2.9 \%)$; evening primrose oil $(1.9 \%)$; 
Table 2: Background characteristics of participants $(n=588)$

\begin{tabular}{|c|c|c|}
\hline Characteristic & No. & $\%$ \\
\hline Age (median, range) & 32 & $(18-46)$ \\
\hline \multicolumn{3}{|l|}{ Marital status $(n=584)$} \\
\hline Married & 422 & 72.3 \\
\hline Living with partner & 118 & 20.2 \\
\hline Has partner, not cohabiting & 17 & 2.9 \\
\hline Single & 21 & 3.6 \\
\hline Separated or divorced & 5 & 0.9 \\
\hline Widowed & 1 & 0.2 \\
\hline \multicolumn{3}{|l|}{ Secondary schooling $(n=584)$} \\
\hline $\begin{array}{l}\text { Completed secondary school to final year } \\
\text { (I2) }\end{array}$ & 475 & 81.3 \\
\hline Did not complete secondary school & 97 & 16.6 \\
\hline Attended primary school only & 10 & 1.7 \\
\hline Did not attend primary school & 2 & 0.3 \\
\hline \multicolumn{3}{|l|}{ Higher education $(n=560)$} \\
\hline Degree or higher & 235 & 42.0 \\
\hline No degree & 325 & 58.0 \\
\hline \multicolumn{3}{|l|}{$\begin{array}{l}\text { Taxable income for the household for } \\
\text { last year, AUD }(n=516)^{*}\end{array}$} \\
\hline$<\$ 20,000$ & 82 & 15.9 \\
\hline$\$ 20,000-\$ 30,000$ & 75 & 14.5 \\
\hline$\$ 30,000-\$ 40,000$ & 66 & 12.8 \\
\hline$\$ 40,000-\$ 50,000$ & 63 & 12.2 \\
\hline$>\$ 50,000$ & 230 & 44.6 \\
\hline \multicolumn{3}{|l|}{$\begin{array}{l}\text { Country of birth (only top } 7 \text { listed) }(n= \\
583)\end{array}$} \\
\hline Australia & 314 & 53.9 \\
\hline Vietnam & 66 & 11.3 \\
\hline China & 31 & 5.3 \\
\hline New Zealand & 18 & 3.1 \\
\hline India & 15 & 2.6 \\
\hline UK and Eire & 13 & 2.2 \\
\hline Turkey & 10 & 1.7 \\
\hline \multicolumn{3}{|l|}{$\begin{array}{l}\text { If not born in Australia, years in Australia } \\
(n=256)\end{array}$} \\
\hline Mean (SD) & 10 & $(s d 9.2)$ \\
\hline Median (range) & 8 & $(0-36)$ \\
\hline \multicolumn{3}{|l|}{ English first language $(n=58 \mathrm{I})$} \\
\hline Yes & 378 & 65.1 \\
\hline \multicolumn{3}{|l|}{ Religion $(n=505)$} \\
\hline Christian & 237 & 46.9 \\
\hline Muslim & 55 & 10.9 \\
\hline Buddhist & 49 & 9.7 \\
\hline Hindu & 8 & 1.6 \\
\hline Other & 4 & 0.8 \\
\hline None & 152 & 30.0 \\
\hline \multicolumn{3}{|l|}{ Pre-pregnancy smoking (579) } \\
\hline None & 436 & 75.3 \\
\hline $1-9$ & 83 & 14.3 \\
\hline $10-19$ & 40 & 6.9 \\
\hline $20-29$ & 16 & 2.8 \\
\hline $30-39$ & 4 & 0.7 \\
\hline$>40$ & 0 & - \\
\hline \multicolumn{3}{|l|}{ Gestation at recruitment $(n=575)$} \\
\hline Mean (sd) & 38.45 & (sd I.28) \\
\hline Median (range) & 38 & $(29-42)$ \\
\hline \multicolumn{3}{|l|}{ First baby $(n=582)$} \\
\hline Yes & 310 & 53.3 \\
\hline \multicolumn{3}{|l|}{$\begin{array}{l}\text { Previous pregnancy losses (could tick more } \\
\text { than one option) }\end{array}$} \\
\hline Termination of pregnancy & 134 & 22.8 \\
\hline Miscarriage (including ectopic pregnancies) & 113 & 19.2 \\
\hline
\end{tabular}


Table 2: Background characteristics of participants $(n=588)$ (Continued)

\begin{tabular}{lll}
\hline Stillbirth $>20$ weeks gestation & 6 & 1.0 \\
$\quad$ Neonatal death & 1 & 0.2 \\
$\quad$ None of these & 353 & 60 \\
Model of pregnancy care $(\mathrm{n}=586)$ & & \\
$\quad$ Public hospital clinic (doctor or midwife) & 280 & 47.7 \\
Shared care (majority of care with local & 171 & 29.2 \\
family doctor) & 93 & 15.9 \\
Team midwifery or midwives clinic & 41 & 7.0 \\
Family Birth Centre & & \\
\hline
\end{tabular}

* Australian average annual income for those is currently employed is $\$ 42,484$ (Australian Bureau of Statistics, Feb 2006, http://www.abs.gov.au); for those not currently employed, Government pensions and allowances provide income support of up to approximately $\$ 10-12,000$ per year http:// www.centrelink.gov.au

Table 3: Herbal supplements women reported using during pregnancy $(n=588)$

\begin{tabular}{|c|c|c|c|c|c|c|c|}
\hline Herb taken & No & $\%$ & $\begin{array}{l}\text { Most common } \\
\text { form of } \\
\text { supplement* }\end{array}$ & $\begin{array}{l}\text { Most common } \\
\text { reason/s for use } \\
\text { reported by } \\
\text { women** }\end{array}$ & $\begin{array}{l}\text { Gestation } \\
\text { commenced (if } \\
\text { applicable) }\end{array}$ & $\begin{array}{l}\text { Who } \\
\text { recommended } \\
\text { supplement use* }\end{array}$ & $\begin{array}{l}\text { \% who } \\
\text { reported the } \\
\text { supplement } \\
\text { helped? }\end{array}$ \\
\hline Raspberry leaf & 83 & 13.9 & $\begin{array}{l}\text { Tea }(7 \mid \%) \\
\text { Tablet }(22 \%) \\
\text { Syrup }(5 \%)\end{array}$ & $\begin{array}{l}\text { Strengthen or tone } \\
\text { uterus ready for } \\
\text { labour }(76 \%)\end{array}$ & $\begin{array}{l}30 \text { weeks or later 63/ } \\
71(89 \%)\end{array}$ & $\begin{array}{l}\text { Friends }(37 \%) \\
\text { Naturopath }(23 \%) \\
\text { Self }(22 \%)\end{array}$ & $N / A$ \\
\hline Ginger & 68 & 11.6 & $\begin{array}{l}\text { Tea }(46 \%) \\
\text { Tablet (40\%) } \\
\text { Syrup (1 } 1 \%)\end{array}$ & Nausea (85\%) & $\begin{array}{l}\text { Early in pregnancy } 58 / \\
59(98 \%)\end{array}$ & $\begin{array}{l}\text { Self }(42 \%) \\
\text { Friends (39\%) } \\
\text { Naturopath (17\%) }\end{array}$ & $43 / 56(76.8 \%)$ \\
\hline Chamomile & 65 & 11.1 & Tea $(100 \%)$ & $\begin{array}{l}\text { Relax/calming/help } \\
\text { sleep }(65 \%) \\
\text { Aid digestion/help } \\
\text { nausea }(25 \%)\end{array}$ & No pattern & $\begin{array}{l}\text { Self }(71 \%) \\
\text { Family (15\%) } \\
\text { Friends (11\%) }\end{array}$ & $45 / 54(83 \%)$ \\
\hline Cranberry juice & 51 & 8.7 & $\begin{array}{l}\text { Syrup/liquid }(9 \mid \%) \\
\text { Juice }(6 \%) \\
\text { Tablet }(2 \%)\end{array}$ & $\begin{array}{l}\text { Prevent/treat urinary } \\
\text { tract infections (56\%) } \\
\text { Vitamin C intake } \\
(19 \%) \\
\text { Enjoy/like it }(16 \%)\end{array}$ & $\begin{array}{l}\text { Early in pregnancy/or } \\
<=20 \text { wks }(68 \%)\end{array}$ & $\begin{array}{l}\text { Self }(63 \%) \\
\text { Friends (14\%) } \\
\text { Local doctor (14\%) }\end{array}$ & $28 / 36(78 \%)$ \\
\hline Echinacea & 17 & 2.9 & $\begin{array}{l}\text { Tablet }(63 \%) \\
\text { Syrup/liquid (25\%) } \\
\text { Tea (I3\%) }\end{array}$ & $\begin{array}{l}\text { Cold/flu ( } 81 \%) \\
\text { Increase immunity } \\
(13 \%)\end{array}$ & No pattern & $\begin{array}{l}\text { Self (59\%) } \\
\text { Friends (18\%) }\end{array}$ & $6 / 13(46 \%)$ \\
\hline $\begin{array}{l}\text { Evening } \\
\text { primrose oil }\end{array}$ & 11 & 1.9 & Tablet (100\%) & No pattern & No pattern & $\begin{array}{l}\text { Self }(36 \%) \\
\text { Friends (36\%) }\end{array}$ & $2 / 7(29 \%)$ \\
\hline $\begin{array}{l}\text { Digestive } \\
\text { bitters }\end{array}$ & 9 & 1.5 & $\begin{array}{l}\text { Syrup/liquid (56\%) } \\
\text { Tablet (44\%) }\end{array}$ & $\begin{array}{l}\text { Digestive disorders } \\
(100 \%)\end{array}$ & No pattern & No pattern & $8 / 9(89 \%)$ \\
\hline Slippery elm & 9 & 1.5 & $\begin{array}{l}\text { Tablet }(56 \%) \\
\text { Powder (33\%) } \\
\text { Tea (II\%) }\end{array}$ & $\begin{array}{l}\text { Digestive disorders } \\
(88 \%)\end{array}$ & No pattern & $\begin{array}{l}\text { Naturopath (33\%) } \\
\text { Self (33\%) }\end{array}$ & $5 / 8(63 \%)$ \\
\hline Garlic & 8 & 1.4 & Tablet (100\%) & Variety of reasons & No pattern & $\begin{array}{l}\text { Self }(50 \%) \\
\text { Family }(50 \%) \\
\text { Naturopath (38\%) }\end{array}$ & $3 / 6(50 \%)$ \\
\hline Chinese herbs & 8 & 1.4 & $\begin{array}{l}\text { Syrup }(50 \%) \\
\text { Tea }(33 \%)\end{array}$ & Variety of reasons & No pattern & Chinese doctor (63\%) & $6 / 8(75 \%)$ \\
\hline
\end{tabular}

* Does not total $100 \%$ as only most common responses included

$*$ More than one answer could be given 
Table 4: Factors predicting any use of herbal supplements $(n=5 \mid 3)$

\begin{tabular}{|c|c|c|c|c|}
\hline & Unadjusted Odds Ratio & $95 \% \mathrm{Cl}$ & Adjusted Odds Ratio & $95 \% \mathrm{Cl}$ \\
\hline \multicolumn{5}{|l|}{ Interpreted version used } \\
\hline No (ref) & I & & I & \\
\hline Yes & 0.23 & $(0.11,0.49)$ & 0.43 & $(0.18,0.98)$ \\
\hline $\begin{array}{l}\text { Age (increase per } 10 \text { years age } \\
\text { increase)\# }\end{array}$ & 10.62 & $(10.23,11.02)$ & 10.66 & $(10.23,11.12)$ \\
\hline \multicolumn{5}{|l|}{ Degree } \\
\hline Has degree or higher (ref) & 1 & & I & \\
\hline Does not have degree & 0.42 & $(0.29,0.61)$ & 0.56 & $(0.38,0.82)$ \\
\hline \multicolumn{5}{|l|}{ Language } \\
\hline English first language (ref) & 1 & & I & \\
\hline English not first language & 0.39 & $(0.26,0.58)$ & 0.51 & $(0.31,0.83)$ \\
\hline \multicolumn{5}{|l|}{ Smoking during pregnancy } \\
\hline Did not smoke (ref) & 1 & & I & \\
\hline Smoked & 0.44 & $(0.22,0.88)$ & 0.41 & $(0.20,0.85)$ \\
\hline \multicolumn{5}{|l|}{ Parity } \\
\hline First baby (ref) & 1 & & I & \\
\hline Subsequent baby & 0.59 & $(0.41,0.85)$ & 0.56 & $(0.37,0.84)$ \\
\hline
\end{tabular}

*All demographic factors entered into model (including whether it was a planned pregnancy and if they had had a previous miscarriage), and only those remaining significant are presented

digestive bitters (1.5\%); slippery elm (1.5\%); garlic $(1.4 \%)$; and Chinese herbal tea (1.4\%). Other herbal supplements mentioned by five or less women were fish oil tablets, herbal teas, blue cohosh, acidophilus tablets, ombeshi plums, homeopathic drops, peppermint and St John's Wort.

For each herbal supplement they used, women were asked to describe what form of the supplement they used; why they used it; when they commenced taking it; when the supplement was ceased; who recommended the supplements use; and if they considered the supplement had been of help. These findings are also shown in Table 3. In most instances the woman herself made a decision to use a supplement - primary maternity care providers were rarely cited as the person recommending supplement use. With most of the herbal remedies there was no pattern to the gestation at which they were commenced, with the exceptions of raspberry leaf, which was used from 30 weeks gestation or later in the $89 \%$ of cases, and ginger, where $98 \%$ of women commenced taking it in early pregnancy. Reasons for supplement use were relatively consistent for each herbal remedy for example, raspberry leaf tea used as a uterine tonic, ginger used for relief of nausea and vomiting. The form in which each herbal supplement was taken varied with all except garlic (tablets used) and chamomile (tea used).

Comparing women who used interpreted versions of the survey compared with those who did not, $12 \%$ of the women who used a translated version took herbal medicine in pregnancy compared with $40 \%$ of the women who used the English version. When considering this as those who had English as a second language compared with those who reported English as a first language, the trend was the same: $43.7 \%$ of women whose first language was English used herbal medicine whereas $22.7 \%$ of women first language was other than English reported using herbal medicine in pregnancy.

Logistic regression was used to explore who was more likely to take herbal supplements of any kind during pregnancy. Demographic factors (age, marital status, secondary and tertiary education, income, Australian-born compared to not, English as first language, non-English speaking background, pre-pregnancy smoking, parity) as well as if the current pregnancy was planned and if the woman had experienced previous pregnancy losses were each tested against the outcome variable of 'using at least one herbal supplement' in this pregnancy. Variables that had a Wald statistic P-value of $\leq 0.2$ were retained in the preliminary model [23]. These were: having a non-English speaking background; age; marital status; secondary and tertiary education; income; being Australian-born compared to not; pre-pregnancy smoking; and having a first baby. Only observations with no missing values in these variables were included in the model $(n=513)$. Age was retained as a continuous variable after checking it had a linear association with the outcome variable. Variables were eliminated one at a time, with variables only retained if the Wald statistic P-value was $\leq 0.05$. The likelihood ratio test was used to test each subsequent model to ensure the newer simpler one did not differ significantly from the previous model. 


\section{Regression analysis outcomes}

Table 4 shows that after adjusting for demographic factors and clinical variables such as previous miscarriage or whether the current pregnancy was planned, the women less likely to used herbal supplements were those who: used an interpreted version of the questionnaire (OR $0.43 ; 95 \%$ CI $0.18,0.98)$; had a language other than English as their first language (OR 0.51; 95\% CI 0.31, 0.83); had not completed a degree (OR 0.56; 95\% CI 0.38, 0.82); smoked during pregnancy (OR 0.41; 95\% CI 0.20, 0.85); or those having other than their first baby (OR 0.56; 95\% CI $0.37,0.84)$. Women who were older were more likely to take herbal supplements, and this association increased with increasing age (OR per 10 year increase in age 10.66; 95\% CI 10.23, 11.12).

\section{Discussion}

Thirty-six percent of the women in this sample used at least one herbal supplement during their current pregnancy. The most common herbal supplements taken were raspberry leaf $(14 \%)$, ginger $(12 \%)$ and chamomile (11\%). The prevalence of herbal supplementation in our data sit within the proportions reported in Australian studies, which ranged from 10-56\%. The characteristics of the women more likely to take herbal supplements in this study were also in keeping with other reports; women who were older, tertiary educated, English-speaking, nonsmokers and primiparous were more likely to take herbal supplements.

Of the women who reported taking herbal supplements, the majority said they did so for pregnancy related reasons (Table 3), whereas one study reported that only $13 \%$ of herbal medicine use in pregnancy was for pregnancyrelated problems [10] and in another the most common reason for the use of herbal supplements was for sleep or relaxation [24]. Women most commonly reported that they had chosen to take the supplements based on their own knowledge, or advice from friends, with naturopaths being the next most common source of advice. Pregnancy care providers such as midwives, general practitioners and obstetricians were rarely reported to have advised herbal supplement use.

We expected that women from different cultural groups may have different patterns of herbal medicine use, and our study included 35\% of women where English was not their first language, $17 \%$ of who used a translated questionnaire. We found that women of English-speaking background were more likely to take herbal supplements, with no difference in vitamin supplement uptake. In the majority of studies identified women of non-English speaking background (or not speaking the most common language in the study context) have not been included $[8,10]$. Others report including women only if there is an interpreter available [7]; or including two languages only [16]. One study specifically excluded women of differing cultural backgrounds because they anticipated that different groups may have different practices in the use of herbal medicine [10].

A limitation of the current study was that we did not ask women if they reported their herbal supplement use to their maternity care provider during pregnancy. A recent Australian study found that more than half of CAM users did not report their use to a doctor prescribing conventional medicines [12]. This important given our relative lack of knowledge of effects of CAMs as well as the potential interactions of CAMs with conventional medicines [12]. Given the high prevalence of the use of complementary therapies and medicines in our community, and the relative lack of evidence of either efficacy or harm, it is important that health care providers do ask about the use of alternative medicines and therapies as a routine. Reasons for not telling may be that patients felt that doctors (or other care providers) may reject the idea of the alternative therapies [25], or that women may assume that if a supplement is 'natural' it is therefore safe.

We made an a priori decision not to include model of care in the regression model as we wanted to know factors related to the women predicted use of herbal supplements, regardless of model of care. We expected that in general women who chose midwifery models of care (and in particular birth centre care) would be more likely to use herbal supplements, and stratified analysis confirmed this assumption. The data also demonstrated that providers of care were not a major influence on why women took herbal supplements.

This is an exploratory study in an area where there is limited existing knowledge. This study therefore adds to what is known on the topic, and may guide clinicians when they are seeking to understand what (if any) supplements women in similar populations may be taking in pregnancy.

\section{Conclusion}

Use of herbal supplements in pregnancy is likely to be relatively high and it is important to ascertain what supplements (if any) women are taking. Pregnancy care providers should be aware of the common herbal supplements used by women, and of the evidence regarding potential benefits or harm. It is important that care providers do not prescribe any treatments, medications or herbal supplements where they are unaware of the evidence supporting their use. 


\section{Competing interests}

The author(s) declare that they have no competing interests.

\section{Authors' contributions}

DF was involved in study design and implementation, data analysis and drafted the manuscript. AD was involved in study design, implementation and coordination, data analysis and participated in drafting the manuscript. GW participated in data analysis, literature searches and helped draft the manuscript. $\mathrm{MB}$ was involved in study design and implementation. EMc was involved in study design including data collection tools and processes. All authors read and approved final manuscript.

\section{Acknowledgements}

Thanks to the women who participated in the study, the research midwives who assisted with recruitment and data entry, particularly Val Bryant and Ellen Mclntyre, and to Sarah de Bomford who asked the question leading to the study.

\section{References}

I. MacLennan A, Wilson D, Taylor A: Prevalence and cost of alternative health in Australia. Lancet 1996, 2:569-573.

2. MacLennan $\mathrm{AH}$, Wilson $\mathrm{DH}, \mathrm{Taylor} \mathrm{AW}$ : The escalating cost and prevalence of alternative medicine. Preventative medicine 2002, 35:166-173.

3. Ernst E: Herbal medicines put into context. BMJ 2003, 327: $88 \mathrm{I}-882$.

4. Eisenberg $D$, Davis $R$, Ettner S: Trends in alternative medicine use in the United States. JAMA 1998, 280:1569-1575.

5. World Health Organization: Fact sheet $N^{\circ} 134$ : Traditional medicine. [http://www.who.int/mediacentre/factsheets/fs/34/en/ print.html].

6. Drew AK: Safety issues in herbal medicine: implications for the health professions. MJA 1997, 166:538-54I.

7. Henry A, Crowther C: Patterns of medication use during and prior to pregnancy: the MAP study. Aust N Z J Obstet Gynaecol 2000, 40:165-I72.

8. Maats F, Crowther C: Patterns of vitamin, mineral and herbal supplement use prior to and during pregnancy. Aust $N Z J$ Obstet Gynaecol 2002, 42:494-496.

9. Gibson P, Powrie R, Star J: Herbal and alternative medicine use during pregnancy: a cross sectional survery. Obstetrics and Gynaecology 200I, 97:s44-s45.

10. Nordeng $\mathrm{H}$, Havnen $\mathrm{G}$ : Use of herbal drugs in pregnancy: a survey among $\mathbf{4 0 0}$ Norwegian women. Pharmacoepidemiology and drug safety 2004, 13:37|-380.

II. Ernst E: Herbal medicinal products during pregnany: are they safe? BJOG 2002, 109:227-235.

12. MacLennan AH, Myers SP, Taylor AW: The continuing use of complementary and alternative medicine in South Australia: costs and beliefs in 2004. MJA 2006, 184:27-31.

13. Kristoffersen S, Atkin P, Shenfield G: Uptake of alternative medicine (letter to the Editor). Lancet 1996, 347:972.

14. Pinn G, Pallett L: Herbal medicine in pregnancy. Complementary therapies in nursing and midwifery 2002, 8:77-80.

15. Hemminki E, Mantyranta T, Malin M, Koponen P: A survey on the use of alternative drugs during pregnancy. Scand J Soc Med 1991, 19:199-204.

16. Hepner DL, Harnett M, Segal S, Camann W, Bader A, Tsen L: Herbal use in parturients. Anesth Analg 2002, 94:690-693.

17. Gharoro EP, Igbafe AA: Pattern of drug use amongst antenatal patients in Benin City, Nigeria. Med Sci Monit 2000, 6:84-87.

18. Hollyer T, Boon H, Georgousis A, Smith M, Einarson A: The use of CAM by women suffering from nausea and vomiting during pregnancy. BMC Complementary and Alternative Medicine 2002, 2: I-6.
19. Tsui B, Dennehy C, Tsourounis C: A survey of dietary supplement use during pregnancy at an academic medical center. American Journal of Obstetrics and Gynecology 200I, 185:433-437.

20. Centers for Disease Control: Epilnfo Version 6. , World Health Organization; 1993.

21. Microsoft Coorporation: Microsoft $®$ Access 2000. 2000.

22. Stata Corporation: STATA statistical data analysis. 82003 [http://www.stata.com]. College Station, Texas, Stata Corporation

23. Lemeshow S: Logistic regeression analysis: course manual: April 2004; Hobart. Volume I. Lemeshow and Hosmer; 2004:2 I4.

24. Byrne M, Semple S, Coulthard K: Complementary medicine use during pregnancy. Australian Pharmacist 2002, 2 1:954-959.

25. Shenfield GM, Atkin PA, Kristofferson S: Alternative medicine: an expanding health industry. MJA 1997, 166:516-517.

26. Attard C, Kohli M, Coleman S, Bradley C, Hux M, Atanackovic G, Torrance G: The burden of illness of severe nausea and vomiting of pregnancy in the United States. American Journal of Obstetrics and Gynecology 2002, 186:s220-s227.

27. Lacroix I, Damase-Michel C, Lapeyre-Mestre M, Montastruc JL: Prescription of drugs during pregnancy in France. Lancet 2000, 356:1735-1376.

28. Westfall RE: Use of anti-emetic herbs in pregnancy: women's choices, and the question of saftey and efficacy. Complementary therapies in nursing and midwifery 2004, 10:30-36.

\section{Pre-publication history}

The pre-publication history for this paper can be accessed here:

http://www.biomedcentral.com/1471-2393/6/21/prepub

Publish with BioMed Central and every scientist can read your work free of charge

"BioMed Central will be the most significant development for disseminating the results of biomedical research in our lifetime. "

Sir Paul Nurse, Cancer Research UK

Your research papers will be:

- available free of charge to the entire biomedical community

- peer reviewed and published immediately upon acceptance

- cited in PubMed and archived on PubMed Central

- yours - you keep the copyright
BioMedcentral 